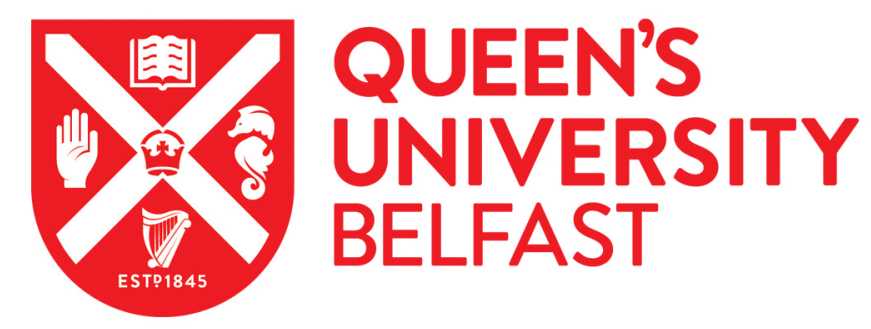

\title{
Autres pays, autres coeurs. Dietary patterns, risk factors and ischaemic heart disease in Belfast and Toulouse
}

Evans, A., Ruidavets, J. B., McCrum, E. E., Cambou, J. P., McClean, R., Douste Blazy, P., McMaster, D., Bingham, A., Patterson, C., Richard, J. L., Mathewson, Z. M., \& Cambien, F. (1995). Autres pays, autres coeurs. Dietary patterns, risk factors and ischaemic heart disease in Belfast and Toulouse. QJM-AN INTERNATIONAL JOURNAL OF MEDICINE, 88, 469-477.

Published in:

QJM-AN INTERNATIONAL JOURNAL OF MEDICINE

Queen's University Belfast - Research Portal:

Link to publication record in Queen's University Belfast Research Portal

\section{General rights}

Copyright for the publications made accessible via the Queen's University Belfast Research Portal is retained by the author(s) and / or other copyright owners and it is a condition of accessing these publications that users recognise and abide by the legal requirements associated with these rights.

Take down policy

The Research Portal is Queen's institutional repository that provides access to Queen's research output. Every effort has been made to ensure that content in the Research Portal does not infringe any person's rights, or applicable UK laws. If you discover content in the Research Portal that you believe breaches copyright or violates any law, please contact openaccess@qub.ac.uk. 


\title{
Original papers
}

\section{Autres pays, autres coeurs? Dietary patterns, risk factors and ischaemic heart disease in Belfast and Toulouse}

\author{
A.E. EVANS ${ }^{1,2}$, J.-B. RUIDAVETS ${ }^{3}$, E.E. MCCRUM ${ }^{1}$, נ.-P. CAMBOU ${ }^{3,4}$, \\ R. MCCLEAN ${ }^{1}$, P. DOUSTE-BLAZY ${ }^{3}$, D. MCMASTER ${ }^{5}$, A. BINGHAM ${ }^{6,7}$, \\ C.C. PATTERSON ${ }^{2}$, J.L. RICHARD ${ }^{6}$, Z.M. MATHEWSON ${ }^{1}$ and F. CAMBIEN ${ }^{8}$ \\ From ${ }^{1}$ MONICA Belfast, the Departments of ${ }^{2}$ Epidemiology and Public Health and ${ }^{5}$ Medicine, \\ Queen's University of Belfast, UK, ${ }^{3}$ MONICA Toulouse, ${ }^{4}$ INSERM U236, Toulouse, France, \\ ${ }^{6}$ MONICA France, ${ }^{7}$ INSERM U258 and ${ }^{8}$ INSERM SC7, Paris, France
}

Received 8 December 1994; Accepted 28 February 1995

\section{Summary}

The WHO MONICA project monitors trends and determinants in cardiovascular disease to relate classical risk factor changes to trends in incidence rates. The Belfast and Toulouse MONICA centres have also collaborated in dietary studies. Both centres have validated incidence and attack rates for ischaemic heart disease using coronary event registration. These data confirm that the disease in middle-aged men is between three and four times as common in Belfast as in Toulouse. Risk factor surveys show some differences between the centres, but the overall risks assessed by two multiple logistic function scoring systems were identical. A weighed dietary survey revealed no important difference in macronutrient intake, although carbohydrate and saturated fat intake in Belfast was significantly higher. Protein, dietary cholesterol and polyunsaturated fat, particularly linoleic acid intake, was significantly higher in Toulouse, as was consumption of wine, cheese, fruit and vegetables, but not potatoes. The Northern Irish diet is typically Northern European, but although the diet in Toulouse has some features of the Mediterranean diet, it is not appreciably different from that in Belfast in terms of total fat intake. Major differences are present for several food items, and in general these differences add support to the antioxidant hypothesis.

\section{Introduction}

The paradox of the low ischaemic heart disease (IHD) mortality of the French in the presence of a moderate intake of fat has been reviewed. ${ }^{1,2}$ Comparison of statutory (Death Certification) IHD rates shows Northern Ireland at the top of the world league and France second from the bottom. French men have about a quarter the IHD rates of men in Northern Ireland; age-standardized rates for IHD
(ICD 410-414) in the 30-69 years age range in 1985 were 94 and 406 per 100000 , respectively. ${ }^{3}$ Belfast and Toulouse are centres for the WHO MONICA Project ${ }^{4}$ which is MONItoring trends and determinants in CArdiovascular disease in more than 20 countries over a decade. MONICA registers IHD events using standard criteria: registration rates in Belfast and Toulouse broadly reflect the large differ-

Address correspondence to Professor A.E. Evans, Department of Epidemiology and Public Health, Mulhouse Building, Grosvenor Road, Belfast BT12 6BJ

(C) Oxford University Press 1995 
ences in the national mortality data. Independent surveys of the MONICA contribution populations establish risk factor trends over time. The dietary contribution to these differences in IHD incidence has been investigated in a joint EC/MONICA Study. ${ }^{5}$ This analysis was undertaken with the aim of comparing IHD incidence, risk factor levels and dietary intake in Belfast and Toulouse.

\section{Methods}

\section{Statutory mortality data}

Both centres compile statutory mortality data for various causes using the standard MONICA protocol.

\section{Registration}

The MONICA Project registers IHD events to rigid criteria, using a common protocol in each centre, ${ }^{4}$ suspected events are documented and the MONICA criteria applied; 28-day survival is recorded. Registration procedures in both centres are comparable, and the main source of ascertainment of fatal cases is through death certification. Information for non-fatal cases is gathered from surveillance of hospital discharges and monitoring events which are cared for at home.

In Belfast, MONICA covers Belfast city and the northern part of County Down, and has a target population of 157300 men and women aged 35-64 years. ${ }^{6}$ In Toulouse, MONICA covers Toulouse city and the rest of the Haute-Garonne region with a target population of 296900 men and women aged $35-64$ years. $^{6}$

\section{Risk factor survey}

In Belfast, the screening took place over a one-year period from 1985-86, and 401 randomly selected subjects were screened; the methodology has been described. ${ }^{7}$ Blood pressure was measured using the Hawksley Random Zero Sphygmomanometer.

In Toulouse, a total of 400 randomly selected subjects were screened over a two-year period; the methodology is given elsewhere. ${ }^{8}$ Blood pressure was measured using a standard mercury sphygmomanometer.

Both centres satisfied the requirements of an external quality control scheme organized by the WHO Lipid Reference Laboratory in Prague, Czechoslovakia.

\section{Dietary survey}

Both centres took part in the joint EC/MONICA Project optional nutrition study. ${ }^{5}$ The subjects studied were those included in the Risk Factor Survey. The recommended instrument was the 3-day food diary. In addition, a $10 \%$ sub-sample of records were to be duplicated using the 3-day precise weighed method.

In Belfast, the 3-day precise weighed method was used for all 401 participants. The number of subjects producing analysable records was 356 (final response rate $52 \%$ ). The methods have been described. ${ }^{9}$

In Toulouse, 3-day food diaries were kept, using estimated weights for food, household measures and portion sizes. These were completed on all 400 subjects who took part (response rate $58 \%$ ). In addition, 40 subjects completed the 3 -day precise weighed method. A description is available elsewhere. ${ }^{10}$ Ethical approval for these studies was received in both centres, and all subjects gave their informed consent.

\section{Statistical analyses}

The risk factor data were compared using the $\chi^{2}$ test and the independent samples t-test, and $95 \% \mathrm{Cls}$ were calculated. In order to obtain as valid a dietary comparison as possible, only 3-day weighed records were analysed. For each Toulouse subject, two Belfast subjects were selected by matching for height, weight and age. The mean values for the two matched groups were compared using analysis of variance. Because of the large number of variables examined, significance was only accepted at the $1 \%$ level.

\section{Results}

\section{Statutory mortality}

Table 1 gives the age-specific statutory mortality per 100000 population (mean 1985-1987) for males aged 45-54 and 55-64 years in the two centres. The IHD statutory mortality rates in Belfast and Toulouse agree with the national mortality data, with a ratio of approximately $4: 1$. Mortality from IHD is approximately three times more common in older males than younger males. In Belfast it accounts for $37 \%$ and $36 \%$ of deaths in younger and older males, respectively; in Toulouse, $12 \%$ and $15 \%$. Stroke in older men in Belfast is twice as common as in Toulouse. Cancer mortality is slightly higher in Belfast; the excess is mainly due to malignant neoplasms of lung, but cancer accounts for a greater proportion of deaths in Toulouse than Belfast. Only for other causes mortality in younger men, and injury and poisoning in all men, does Belfast fair better. All these differences are reflected in the all causes mortality which is almost $40 \%$ higher in Belfast than Toulouse in younger males and nearly twice as high in older males. 
Table 1 Age-specific statutory mortality data in two MONICA study areas (1985-1987)

\begin{tabular}{|c|c|c|c|c|c|c|}
\hline \multirow{4}{*}{$\begin{array}{l}\text { Cause of } \\
\text { death }\end{array}$} & \multicolumn{6}{|c|}{ Males $45-54$ years } \\
\hline & \multirow[t]{3}{*}{ ICD No. } & \multicolumn{2}{|c|}{ Rate/100000 } & \multirow{2}{*}{\multicolumn{2}{|c|}{$\begin{array}{l}\text { Proportional } \\
\text { mortality (\%) }\end{array}$}} & \multirow{3}{*}{$\begin{array}{l}\text { Ratio } \\
\text { of rates } \\
(\mathrm{B} / \mathrm{T})\end{array}$} \\
\hline & & \multirow{2}{*}{ Belfast } & \multirow{2}{*}{ Toulouse } & & & \\
\hline & & & & Belfast & Toulouse & \\
\hline Ischaemic heart disease & $410-414$ & 237 & 56 & 37 & 12 & $4.2: 1$ \\
\hline Stroke & $430-438$ & 32 & 24 & 5 & 5 & $1.3: 1$ \\
\hline Other cardiovascular disease & $\begin{array}{l}\text { Rest of } \\
390-459\end{array}$ & 30 & 22 & 5 & 5 & $1.4: 1$ \\
\hline Cancer & $140-208$ & 188 & 159 & 30 & 35 & $1.2: 1$ \\
\hline Injury and poisoning & E800-E999 & 59 & 75 & 9 & 16 & $0.8: 1$ \\
\hline Other & All others & 91 & 122 & 14 & 27 & $0.8: 1$ \\
\hline All causes & & 638 & 459 & 100 & 100 & $1.4: 1$ \\
\hline \multirow{4}{*}{$\begin{array}{l}\text { Cause of } \\
\text { death }\end{array}$} & \multicolumn{6}{|c|}{ Males $55-64$ years } \\
\hline & \multirow[t]{3}{*}{ ICD No. } & \multicolumn{2}{|c|}{ Rate/100000 } & \multirow{2}{*}{\multicolumn{2}{|c|}{$\begin{array}{l}\text { Proportional } \\
\text { mortality (\%) }\end{array}$}} & \multirow{3}{*}{$\begin{array}{l}\text { Ratio } \\
\text { of rates } \\
(\mathrm{B} / \mathrm{T})\end{array}$} \\
\hline & & \multirow{2}{*}{ Belfast } & \multirow{2}{*}{ Toulouse } & & & \\
\hline & & & & Belfast & Toulouse & \\
\hline Ischaemic heart disease & $410-414$ & 761 & 175 & 36 & 15 & $4.3: 1$ \\
\hline Stroke & $430-438$ & 130 & 61 & 6 & 5 & $2.1: 1$ \\
\hline \multirow[t]{2}{*}{ Other cardiovascular disease } & \multicolumn{5}{|l|}{ Rest of } & \\
\hline & $390-459$ & 130 & 92 & 6 & 8 & $1.4: 1$ \\
\hline Cancer & $140-208$ & 694 & 515 & 33 & 43 & $1.3: 1$ \\
\hline Injury and poisoning & E800-E999 & 67 & 73 & 3 & 6 & $0.9: 1$ \\
\hline Other & All others & 330 & 280 & 16 & 23 & $1.2: 1$ \\
\hline \multicolumn{2}{|l|}{ All causes } & 2112 & 1197 & 100 & 100 & $1.8: 1$ \\
\hline
\end{tabular}

\section{Registration}

Table 2 gives the age-specific coronary event rates classified to MONICA criteria: these show mortality rates and incidence rates. The $4: 1$ relationship observed for statutory mortality rates is reflected in the MONICA validated mortality rates, but is lower due to the strict MONICA diagnostic criteria. Case fatality is rather higher in Belfast. As expected, case fatality increases in both centres with age.

\section{Risk factor survey}

In Table 3, mean risk factor profiles are given for all subjects who completed the dietary study. A higher proportion of younger males in Toulouse reported diabetes than in Belfast; the difference was even greater in older males ( $p=0.005$ ). Overall, $45 \%$ of those reporting diabetes in Belfast were on drug treatment, $36 \%$ on insulin. In Toulouse the proportion was $59 \%$ (none on insulin). More younger subjects were hypertensive in Toulouse than in Belfast, the difference was significant in the older men ( $p=$ 0.002 ). Overall, $30 \%$ of the total classified as hyper- tensive were on treatment in Belfast, and of these $43 \%$ were controlled; the respective proportions in Toulouse were $36 \%$ and $33 \%$. Cigarette smoking in younger men was slightly more common in Toulouse, and this difference was very pronounced in older men ( $p=0.004$ ). Mean serum cholesterol was higher in Belfast in younger men, the reverse held for HDLcholesterol $(p<0.001)$. In Belfast, only one subject $(0.3 \%)$ claimed to be on hypolipidaemic therapyin Toulouse $31(7.8 \%)$ claimed to be on it. Systolic blood pressure was higher in Belfast men and diastolic blood pressure lower; mean blood pressure was lower in Belfast than Toulouse. Body mass indices were very similar in the two centres. These risk factor levels translated into two almost identical multiple logistic function (MLF) estimates ${ }^{11,12}$ of the risk of developing $\mathrm{CHD}$ over the next $4-5$ years in each age range.

\section{Dietary survey}

The results are given for the entire age range (45-64 years) for the 40 subjects in Toulouse and the 80 
Table 2 Coronary event registration to MONICA criteria ${ }^{4}(1985-87)$

\begin{tabular}{|c|c|c|c|}
\hline \multicolumn{4}{|c|}{ Males $45-54$ years } \\
\hline & Belfast & Toulouse & $\begin{array}{l}\text { Ratio } \\
(\mathrm{B} / \mathrm{T})\end{array}$ \\
\hline Mortality rate* (first events) & 130 & 33 & $3.9: 1$ \\
\hline Mortality rate* (all events) & 223 & 47 & $4.7: 1$ \\
\hline Incidence rate ${ }^{* *}$ (first events) & 482 & 138 & $3.5: 1$ \\
\hline Attack rate** (all events) & 679 & 168 & $4.0: 1$ \\
\hline Case fatality*** (first events) & $27.1 \%$ & $23.7 \%$ & $1.1: 1$ \\
\hline Case fatality*** (all events) & $32.9 \%$ & $27.8 \%$ & $1.2: 1$ \\
\hline \multicolumn{4}{|c|}{ Males $55-64$ years } \\
\hline Mortality rate* (first event) & 358 & 92 & $3.9: 1$ \\
\hline Mortality rate* (all events) & 673 & 155 & $4.3: 1$ \\
\hline Incidence rate ${ }^{* *}$ (first events) & 1019 & 307 & $3.3: 1$ \\
\hline Attack rate** (all events) & 1634 & 416 & $3.9: 1$ \\
\hline Case fatality*** (first events) & $35.2 \%$ & $30.0 \%$ & $1.2: 1$ \\
\hline Case fatality*** (all events) & 41.2 & $37.2 \%$ & $1.1: 1$ \\
\hline
\end{tabular}

All rates are age-specific rates $/ 100000$.

* Fatal: MONICA Definite and Possible categories.

** Fatal: MONICA Definite and Possible categories, non-fatal: MONICA Definite category.

*** Case fatality $=100 \times$ Fatal: Definite and Possible $\div$ (Fatal: Definite and Possible + Non-fatal: Definite)

subjects (matched by age, height and weight) in Belfast. Total energy intake was almost identical (Table 4) and there was no significant difference in the intake of total fat. Carbohydrate intake was higher in Belfast than Toulouse. Protein and dietary cholesterol intake were higher in Toulouse than Belfast $(p<0.001)$.

Monounsaturated fatty acid intake did not differ significantly. Saturated and polyunsaturated fatty acid intake was higher in Toulouse than Belfast $(p<0.004$ and $p<0.001)$, as was linoleic acid intake $(p=0.002)$. Alcohol consumption was greater in Toulouse. Red wine was the main alcoholic beverage in Toulouse $(70 \%$ of men drank it almost every day) but in Belfast beer and spirits predominated. Calcium intake in Belfast was greater than in Toulouse, as was sugar $(p=0.002)$. There was no significant difference in magnesium, starch and fibre intake.

The energy supplied by protein was highly significantly greater $(p<0.001)$ in Toulouse but there was no significant difference in energy supplied by fat (Table 5). Differences emerged for alcohol and saturated fatty acids ( $p=0.002)$ but not for carbohydrates or monounsaturated fatty acid intake. Polyunsaturated fatty acids contributed very significantly more to total energy in Toulouse $(p<0.001)$. This was reflected in a higher P/S Ratio $(p<0.001)$.

Figure 1 gives the percentage contribution of foods to total energy. Bread contributed almost equally, but biscuits and cakes contributed much more in Belfast $(p=0.005)$. Meats supplied a significantly greater proportion $(p=0.002)$ in Toulouse, but fish consumption did not differ to any important extent. Milk and cream consumption was slightly higher in Belfast, as was butter consumption, but cheese consumption was highly significantly greater $(p<0.001)$ in Toulouse. Non-cottage cheese consumption was more than three times higher in Toulouse $16.6 \%$ of total calories vs. $2.1 \%$ in Belfast $)(p<0.001)$. Taken together, dairy products accounted for $18.4 \%$ of total energy in Toulouse and $15.3 \%$ in Belfast. Consumption of potatoes was very significantly higher in Belfast $(p<0.001)$ but the reverse held for vegetables in Toulouse $(p=0.009)$. Both sets of National Food Tables are in harmony in classifying tomatoes as vegetables: when these were removed, the difference in vegetable consumption was no longer significant (tomatoes contributed $0.14 \%$ to total energy in Belfast and $0.83 \%$ in Toulouse-a sixfold difference, $p<0.001$ ). The contribution from cabbage and broccoli, etc. was threefold $(0.13 \%$ in Belfast vs. $0.35 \%$ in Toulouse), and similarly for carrots $(0.08 \%$ in Belfast vs. $0.33 \%$ in Toulouse) $(p=0.001)$. The reverse was true for onions $(0.44 \%$ in Belfast vs. $0.10 \%$ in Toulouse). No significant differences emerged for cucumber or spinach. There was a greater than fourfold difference in fruit consumption $1.7 \%$ in Belfast vs. $7.1 \%$ in Toulouse) $(p<0.001)$. The contribution from citrus 
Table 3 Risk factor profiles

\begin{tabular}{|c|c|c|c|c|}
\hline & \multicolumn{4}{|l|}{$45-54$ years } \\
\hline & Belfast & Toulouse & Difference $(95 \% \mathrm{Cl})$ & $p$ \\
\hline$n$ & 155 & 204 & & \\
\hline Diabetes (\%) & 2.6 & 7.2 & $4.6(0.1,9.1)$ & 0.06 \\
\hline Hypertensive (\%) & 20.6 & 27.5 & $6.8(-2.0,15.6)$ & 0.14 \\
\hline Current cig. smoker (\%) & 32.3 & 35.3 & $3.0(-6.8,12.9)$ & 0.55 \\
\hline Chblesterol (mmol/l) & $6.19(1.06)$ & $5.94(1.05)$ & $0.25(0.03,0.47)$ & 0.03 \\
\hline HDL-cholesterol $(\mathrm{mmol} / \mathrm{l})$ & $1.22(0.31)$ & $1.39(0.39)$ & $-0.17(-0.25,-0.09)$ & $<0.001$ \\
\hline Systolic BP (mmHg) & $134.0(17.6)$ & $131.9(17.7)$ & $2.10(-1.61,5.81)$ & 0.26 \\
\hline Diastolic BP (mmHg) & $85.0(10.0)$ & $87.2(12.9)$ & $-2.20(-4.66,0.26)$ & 0.07 \\
\hline Mean BP $(\mathrm{mmHg})$ & $101.3(11.6)$ & $102.1(13.9)$ & $-0.80(-3.52,1.92)$ & 0.57 \\
\hline BMl $\left(\mathrm{kg} / \mathrm{m}^{2}\right)$ & $26.3(3.4)$ & $26.0(3.4)$ & $0.30(-0.41,1.01)$ & 0.44 \\
\hline Probability of $\mathrm{CHD}^{*}$ & 0.016 & 0.015 & & \\
\hline \multirow[t]{2}{*}{ Probability of CHD** } & 0.024 & 0.021 & & \\
\hline & \multicolumn{4}{|l|}{$55-64$ years } \\
\hline$n$ & 201 & 196 & & \\
\hline Diabetes (\%) & 3.5 & 10.9 & $7.4(2.2,12.7)$ & 0.005 \\
\hline Hypertensive (\%) & 33.5 & 49.0 & $15.5(5.9,25.1)$ & 0.002 \\
\hline Current cig. smoker (\%) & 22.9 & 36.2 & $13.3(4.5,22.2)$ & 0.004 \\
\hline Cholesterol $(\mathrm{mmol} / \mathrm{l})$ & $6.12(1.01)$ & $5.98(1.01)$ & $0.14(-0.06,0.34)$ & 0.16 \\
\hline HDL-chol. (mmol/l) & $1.28(0.37)$ & $1.34(0.35)$ & $-0.06(-0.13,0.01)$ & 0.10 \\
\hline Systolic BP (mmHG) & $142.9(22.1)$ & $139.7(15.7)$ & $3.20(-0.61,7.01)$ & 0.09 \\
\hline Diastolic BP (mmHg) & $84.2(11.9)$ & $90.3(11.6)$ & $-6.10(-8.43,-3.77)$ & $<0.001$ \\
\hline Mean BP (mmHg) & $103.8(13.9)$ & $106.7(12.2)$ & $-2.90(-5.49,-0.31)$ & 0.03 \\
\hline BMI $\left(\mathrm{kg} / \mathrm{m}^{2}\right)$ & $26.7(4.2)$ & $26.4(3.4)$ & $0.30(-0.45,1.05)$ & 0.39 \\
\hline Probability of $\mathrm{CHD}^{*}$ & 0.042 & 0.041 & & \\
\hline Probability of $\mathrm{CHD}^{* *}$ & 0.050 & 0.055 & & \\
\hline
\end{tabular}

Data for non-percentage factors are means (SD).

* MLF score (UKHDPP - age, cigs, chol, systolic BP \& BMI). ${ }^{11}$

** MLF score (BRHS - age, cigs, chol, HDL-chol, mean BP \& BMl). ${ }^{12}$

Hypertensive, systolic $\mathrm{BP} \geqslant 140$ and diastolic $\mathrm{BP} \geqslant 90 \mathrm{mmHg}$, or receiving treatment; mean BP, $($ systolic $+($ diastolic $\times 2)) \div 3$.

fruits revealed a threefold difference (Belfast $0.37 \%$ vs. $1.10 \%$ in Toulouse). Massive differences were observed in the contribution from apples $(0.12 \%$ in Belfast vs. $2.76 \%$ in Toulouse) $(p<0.0001)$. Differences also emerged in terms of nut consumption: $0.34 \%$ in Belfast and $0.67 \%$ in Toulouse, but this was not statistically significant. In Toulouse, on average, $0.37 \mathrm{~g}$ garlic per day were consumed-in Belfast a tiny minority of men used it.

\section{Discussion}

A stark contrast in angina pectoris between Ireland and France was noticed nearly two centuries ago by Samuel Black, an Irish Physician ${ }^{13}$-it is still present. Dr Black thought that the French might be spared because of 'the benignity of their climate'. Although there is a big difference in climate between Belfast and Toulouse, there is a much lesser difference between Belfast and Lille in northern France, where heart disease is almost as rare as in Toulouse. ${ }^{4}$

Because of the very low incidence of $\mathrm{CHD}$ in France despite a fat intake which is not particularly low, a 'French paradox' is repeatedly cited. ${ }^{1,2}$ The pitfalls in international comparisons of IHD mortality rates due to differences in death certification and coding methodology have been highlighted. ${ }^{14,15}$ Such limitations were not observed: MONICA mortality data reflected the statutory data, although the rates were slightly lower. There was a four-fold higher IHD mortality in Belfast than in Toulouse, and all causes mortality was almost twice as high in Belfast in older males. This comparison of IHD incidence and mortality between France and the UK has used validated data collected to a standardized protocol. In men aged 35-64 years in Toulouse, there was a larger proportion of unclassifiable deaths than in Belfast. ${ }^{4}$ If some of these were IHD deaths, they would have increased the mortality from IHD, but 
Table 4 Mean nutrient intake

\begin{tabular}{|c|c|c|c|c|}
\hline & Belfast & Toulouse & $\begin{array}{l}\text { Difference in } \\
\text { means }(95 \% \mathrm{Cl})\end{array}$ & $p$ \\
\hline$n$ & 80 & 40 & & \\
\hline Age & $55.4(5.5)$ & $55.1(6.0)$ & $0.3(-1.1,1.7)$ & 0.45 \\
\hline Total energy (kcal) & $2340(566)$ & $2295(522)$ & $-45(-183,272)$ & 0.67 \\
\hline Protein $(g)$ & $82.8(21.9)$ & $96.8(20.1)$ & $-14(-22.7,-5.3)$ & $<0.001$ \\
\hline Fat $(g)$ & $99.8(31.6)$ & $92.3(25.9)$ & $7.5(-5.0,20.0)$ & 0.16 \\
\hline Carbohydrate (g) & $270(84)$ & $235(79)$ & $35(4,66)$ & 0.02 \\
\hline Cholesterol (mg) & $319(183)$ & 479 (168) & $-160(-231,-88)$ & $<0.001$ \\
\hline \multicolumn{5}{|l|}{ Fatty acids: } \\
\hline Saturated (g) & $42.8(18.1)$ & $35.3(10.7)$ & $7.5(1.1,13.9)$ & 0.004 \\
\hline Mono $(\mathrm{g})$ & $36.6(20.4)$ & $33.1(11.5)$ & $3.6(-3.4,10.6)$ & 0.23 \\
\hline Poly (g) & $12.0(6.7)$ & $17.0(8.0)$ & $-5.0(-7.7,-2.3)$ & $<0.001$ \\
\hline Linoleic acid (g) & $9.6(6.2)$ & $13.8(7.2)$ & $-4.2(-6.6,-1.8)$ & 0.002 \\
\hline Alcohol $(\mathrm{g})$ & $12.1(21.5)$ & $21.7(19.2)$ & $-9.6(-17.3,-1.9)$ & 0.01 \\
\hline Calcium (mg) & $971(316)$ & $850(293)$ & $120(15,225)$ & 0.04 \\
\hline Magnesium (mg) & $321(107)$ & $352(94)$ & $-30(-70,9)$ & 0.11 \\
\hline Sugar (g) & $104.0(48.4)$ & $79.1(39.0)$ & $24.9(7.8,42.0)$ & 0.002 \\
\hline Starch (g) & $151(53)$ & $143(55)$ & $7.3(-14,28)$ & 0.49 \\
\hline Fibre $(\mathrm{g})$ & $21.1(9.2)$ & $19.5(7.0)$ & $1.6(-1.4,4.6)$ & 0.28 \\
\hline
\end{tabular}

Data are means (SD).

Table 5 Mean energy supplied by nutrients (including alcohol)

\begin{tabular}{|c|c|c|c|c|}
\hline & Belfast & Toulouse & $\begin{array}{l}\text { Difference in } \\
\text { means }(95 \% \mathrm{Cls})\end{array}$ & $p$ \\
\hline$n$ & 80 & 40 & & \\
\hline Protein $(\%)$ & $14.3(2.8)$ & $17.3(3.6)$ & $-3.0(-4.1,-1.9)$ & $<0.001$ \\
\hline Fat $(\%)$ & $38.1(6.3)$ & $36.4(6.9)$ & $1.7(-1.0,4.4)$ & 0.19 \\
\hline Carbohydrate (\%) & $43.4(8.2)$ & $40.6(7.1)$ & $2.8(0.0,5.6)$ & 0.054 \\
\hline Alcohol $(\%)$ & $3.6(6.2)$ & $6.4(5.4)$ & $-2.8(-5.0,-0.6)$ & 0.01 \\
\hline \multicolumn{5}{|l|}{ Fatty acids } \\
\hline Saturated $(\%)$ & $16.3(4.7)$ & $14.0(3.5)$ & $2.3(0.7,3.9)$ & 0.002 \\
\hline Mono (\%) & $13.9(6.1)$ & $13.0(3.3)$ & $0.9(-1.0,2.8)$ & 0.29 \\
\hline Poly (\%) & $4.6(2.2)$ & $6.6(2.7)$ & $-2.0(-2.9,-1.1)$ & $<0.001$ \\
\hline P/S Ratio & $0.30(0.19)$ & $0.51(0.29)$ & $-0.21(-0.29,-0.11)$ & $<0.001$ \\
\hline
\end{tabular}

Data are means (SD).

by not enough to have any profound effect on the ranking. The higher mortality due to injury and poisoning in Toulouse was surprising in view of Belfast's 'troubles' but road traffic deaths were more common in Toulouse. Case fatality rates were higher in Belfast: this could be an effect of earlier admission due to mobile coronary care and hence better diagnostic criteria in fatal events (this would have very little effect on the overall mortality classification rates), or it could be due to fewer sudden deaths in Toulouse.

Self-reported diabetes was almost three times as common in Toulouse as in Belfast, and judging by drug treatment, these differences were real. The different methods of measuring blood pressure may have introduced a systematic bias. The use of the
Random Zero device (in Belfast) gives a lower blood pressure recording by around $2 \mathrm{mmHg}$ diastolic than the standard sphygmomanometer; this may be due to an increased height of the mercury in the Random Zero manometer tube. ${ }^{16}$

Some differences were noted for cigarette smoking and HDL cholesterol, but most other risk factors were similar in the two samples. The very much higher self-reported level of hypolipidaemic treatment in Toulouse is unlikely to have contributed significantly to the very low CHD incidence observed. The MLF scores, although higher in the older age range, showed no difference between the centres. The use of MLF scores in new populations is open to criticism ${ }^{17}$ but the simultaneous study of the same age-sex groups should give reasonable 


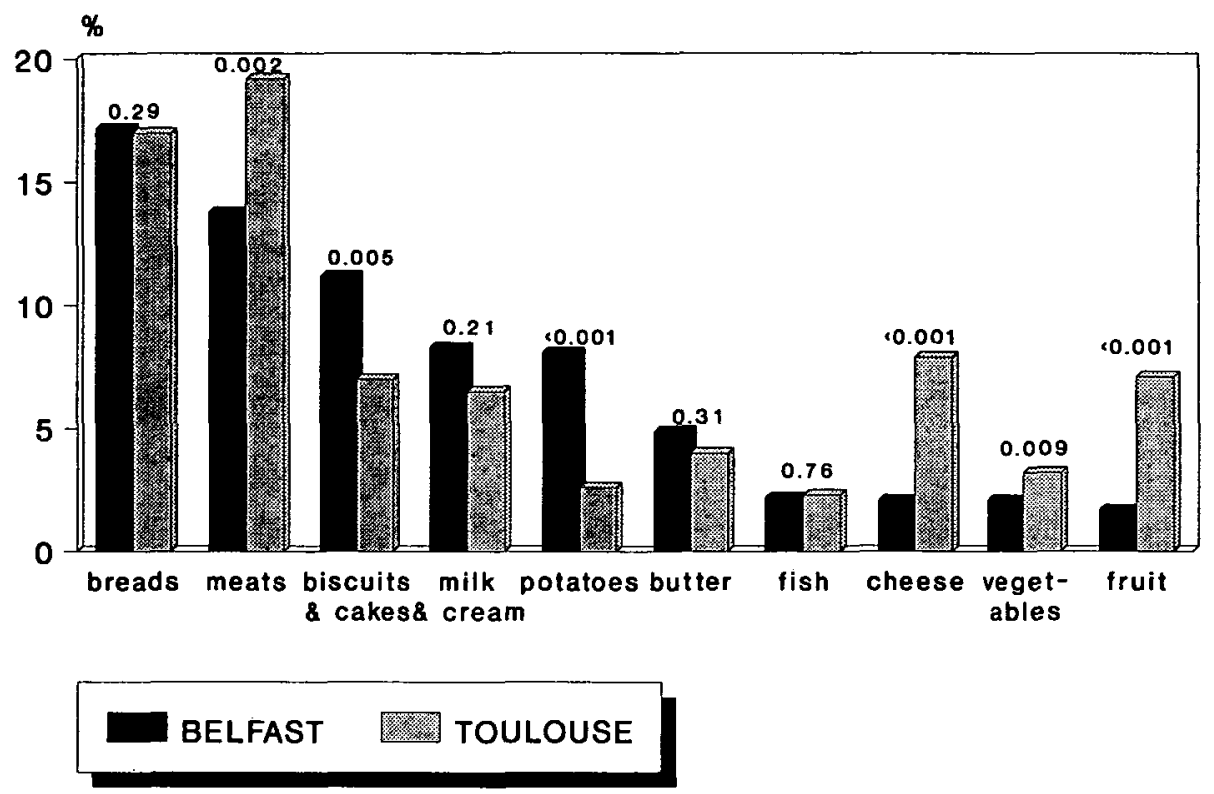

Figure 1. Percentage contribution of foods to total energy in the diet. Figures above columns are $p$ values.

estimates of risk in the two populations. Besides, both MLFs were derived in a population juxtaposed between the two study populations which has intermediate IHD rates.

Poor response may have introduced bias. However, both centres showed low response rates, as is typical of dietary surveys; also the weighed dietary study was of limited size. It is tempting to assume that a similar cross-section of the population attended in each centre, but this cannot be easily verified. However, risk factor levels in this survey were similar to those of the main MONICA screening surveys where response rates were higher. Another possible source of bias is the accuracy of the national food tables.

Neither the classic risk factor scores nor the similarity in major nutrient intake adequately explain the large differences in IHD and other causes mortality between the centres. Total energy intake did not differ, and it is unlikely that this confounded with different energy expenditures as the BMls were also almost identical (in the risk factor comparison). Total fat consumption did not differ significantly between the centres, but protein and dietary cholesterol intake did. Polyunsaturated fatty acid and linoleic acid intake was higher in Toulouse and saturated fatty acid intake was higher in Belfast. The higher PS ratio in Toulouse could be bestowing a greater benefit than is commonly thought. Biscuits and cakes as an energy source was very much greater in Belfast where they are the largest single source of fat in the diet. ${ }^{18}$ The much higher cheese consumption in Toulouse should ensure a higher calcium intake which may exert a protective effect, at least in rabbits, ${ }^{19}$ but in Belfast calcium intake was higher.
Alcohol consumption in Toulouse was significantly higher than in Belfast: the Toulousains drink red wine rather than beer and spirits and drink daily; in Belfast fewer people drink but the rest make up for it, particularly in bout drinking at weekends. Large studies have now shown ${ }^{20,21}$ a reduced relative risk for IHD in moderate drinkers. It is postulated that a steady consumption of wine in France reduces platelet aggregation, ${ }^{22}$ and that bout drinking induces rebound aggregation. Flavonoids and phenols in red wine, including anthocyanin which imparts its colour, and resveratrol may also play a role as antioxidants. ${ }^{23}$ There is now some evidence that red wine consumption reduces lipoprotein(a) ${ }^{24}$ and this could in turn elevate levels of tissue growth factor $-\beta$ which has been shown ${ }^{25}$ to be very low in advanced atherosclerosis.

The difference in tomato and fruit intake fits with the antioxidant hypothesis. The much higher level of tomato consumption in Toulouse demands further study in view of the singlet oxygen-quenching potential of lycopene, whose major source is tomatoes. ${ }^{26}$ Recently, lycopene has been found ${ }^{27}$ to be twice as effective as beta carotene in protecting lymphocyte cells from $\mathrm{NO}_{2}$ radical damage. The strikingly higher apple intake in Toulouse is intriguing, as in the Zutphen Elderly Study, flavonoid consumption was inversely related to CHD death. ${ }^{28}$ The major sources of flavonoids in the Netherlands, in particular quercetin, were tea, onions and apples. In Belfast tea is drunk with milk which may decrease its bioavailability. Onion consumption was greater in Belfast, but this would have been more than offset by the consumption of apples in Toulouse. Turning to other antioxidants, although the Belfast population 
may compensate for a low vitamin $C$ intake from fruit and vegetables by a higher intake of potatoes, this may be offset by cooking methods and peeling, as serum vitamin $C$ levels in 40-49-year-old males in Belfast are only half those in Toulouse, ${ }^{29}$ plasma vitamin $E$ levels were not very different. $A$ direct comparison of vitamin $C$ and vitamin $E$ intakes is not possible within this dietary comparison, as the French food tables do not allow their calculation.

\section{Acknowledgements}

MONICA Belfast was supported by the DHSS (NI), the MRC (UK) and the NICHSA; Toulouse MONICA by INSERM and a CNAMTS-INSERM agreement, ASTRA CALVE and CIDIL. We also thank Professor R.F. Heller and Professor A.G. Shaper for use of the multiple logistic function scoring systems.

\section{References}

1. Tunstall-Pedoe H. Autres pays, autre moeurs. Theories on why the French have less heart disease than the British. $\mathrm{Br}$ Med J 1988; 297:1559-60.

2. Renaud S, De Lorgeril M. Wine, alcohol, platelets, and the French paradox for coronary heart disease. Lancet 1992; 339:1523-6.

3. Uemura K, Pisa Z. Trends in cardiovascular disease mortality in industrialised countries since 1950 . WId HIth Statist Quart 1988; 41:155-78.

4. WHO MONICA Project. Prepared by Tunstall-Pedoe $\mathrm{H}_{t}$ Kuulasmaa K, Amouyel P, Arveiler D, Rajakangas A-M, Pajak A. Myocardial infarction and coronary deaths in the WHO MONICA Project. Registration procedures, event rates and case-fatality rates in 38 populations from 21 countries in 4 continents. Circulation 1994; 90:583-612.

5. Knuiman JT, Pietinen $P$, de Backer GG, Ducimetière $P$. The MONICA-Project: Optional Study on the surveillance of the dietary intake of the population with regard to cardiovascular diseases. Manual of Operations, EURONUT Report 6. The Netherlands 1985.

6. World Health Organization MONICA Project Principal Investigators. Geographical variation in the major risk factors of coronary heart disease in men and women aged 35-64 years. Wld Hlth Statis Quart 1988; 41:115-40.

7. Evans AE, Kerr MMcF, McCrum EE, McMaster D, McCartney LK, Mallaghan M, Patterson CC. Coronary risk factor prevalence in a high incidence area: results from the Belfast MONICA Project. U Med J 1989; 58:60-8.

8. Douste-Blazy P, Ruidavets J-B, Arveiler D, Bingham A, Camaré $R$, Shaffer $P$, Aby MA, Richard JL. Comparisons of cardiovascular risk factors in two French populations: Haute-Garonne (Toulouse) and Bas-Rhin (Strasbourg). Acta Med Scand 1988; Suppl 728:137-43.

9. McClean R, McCrum E, Scally G, McMaster D, Patterson C, Jackson N, Evans E. Dietary patterns in the Belfast MONICA Project. Proc Nut Soc 1990; 49:297-305.

10. Jost JP, Simon C, Nuttens MC, Bingham A, Ruidavets JB, Cambou JP, Arveiler D, Lecerf JM, Schlienger JL, DousteBlazy P. Comparison of dietary patterns between population samples in the three French MONICA nutritional surveys. Rev Epidém et Santé Publique 1990; 38:517-23.

11. Heller RF, Chinn S, Tunstall-Pedoe H, Rose G. How well can we predict the development of ischaemic heart disease? Experience from the UK heart disease prevention project. $\mathrm{Br}$ Med/ 1984; 288:1408-10.

12. Shaper AP, Pocock SI, Walker M, Phillips AN, Whitehead TP, MacFarlane PW. Risk factors for ischaemic heart disease: the prospective phase of the British Regional Heart Study. I Epidemiol Community Health 1985; 39:197-209.

13. Black S. Clinical and pathological reports. Alex Wilkinson, Newry, 1819:47.

14. Lenère J. Cardiopathies par athérosclérose coronarienne. Revue Prat 1958; 8:1767-856.

15. Stamler J. Opportunities and pitfalls in international comparisons related to patterns, trends and determinants of CHD mortality. Int J Epidemiol 1989; 18:S3-S18.

16. De Gaudemaris G, Folson AR, Prineas RJ, Luepker RV. The Random-Zero versus the standard mercury sphygmomanometer: a systematic blood pressure difference. Am J Epidemiol 1985; 121:282-90.

17. Chambless LE, Dobson AJ, Patterson CC, Raines B. On the use of a logistic risk score in predicting risk of coronary heart disease. Stats in Medicine 1990; 9:385-96.

18. Evans AE, McCrum EE, McClean R, Scally G, McMaster D, Patterson CC. Sources of fat in the Northern Irish diet. Rev Epidém et Santé Publ 1990; 38:545-50.

19. Renaud S, De Lorgeril. Dietary lipids and their relation to ischaemic heart disease: from epidemiology to prevention. Ann Intern Med 1989; 225:39-46.

20. Boffetta P, Garfinkel L. Alcohol drinking and mortality among men enrolled in an American Cancer Society prospective study. Epidemio/ 1990; 1:342-8.

21. Rimm EB, Giovannucci EL, Willett WC, Colditz GA, Ascherio A, Rosner B, Stampfer MJ. Prospective study of alcohol consumption and risk of coronary disease in men. Lancet 1991; 338:464-8.

22. Frankel EN, Kanner J, German JB, Parks SE, Kinsella JE. Inhibition of oxidation of human low-density lipoprotein by phenolic substances in red wine. Lancet $1993 ;$ 341:454-7.

23. Editorial. Does wine work? Clin Chem 1995; 41:14-16.

24. Sharpe PC, McGrath LT, MCClean E, Young IS, Archbold GPR. Effect of red wine consumption on lipoprotein (a) and other risk factors for atherosclerosis. Q J Med 1995; 88:101-8.

25. Grainger DJ, Kemp PR, Metcalfe JC, Liu AC, Lawn RM, Williams NR, Grace AA, Schofield PM, Chauhan A. The serum concentration of active transforming growth factor- $\beta$ is severely depressed in advanced atherosclerosis. Nature Med 1995; 1:74-9.

26. Stahl W, Sies H. Uptake of lycopene and its geometrical isomer is greater from heat-processed than from unprocessed tomato juice in humans. I Nutr 1992; 122:2161-6.

27. Hertog MGL, Feskens EJM, Hollman PCH, Katan MB, Kromhout $D$. Dietary antioxidant flavonoids and risk of coronary heart disease: the Zutphen Elderly Study. Lancet 1993; 347:1007-11.

28. Böhm F, Tinkler JH, Truscott TG. Carotenoids protect against cell membrane damage by nitrogen dioxide radical (Letter). Nature Med 1995; 1:98-9.

29. Gey KF, Puska P, Jordan $P$, Moser $P$. Inverse correlation between plasma Vitamin $E$ and mortality from ischemic 
heart disease in cross-cultural epidemiology. Am / Clin Nutr 1991; 53:326S-34S.

30. Logan RL, Riemersma RA, Thomson M, Oliver MF, Olsson AG, Walldius G, Rossner S, Kaijser L, Callmer E, Carlson LA, Lockerbie L, Lutz W. Risk factors for ischaemic heartdisease in normal men aged 40. Edinburgh-Stockholm study. Lancet 1978; i:949-54.

31. Fraser GE, Sabaté J, Beeson WL, Strahan TM. A possible protective effect of nut consumption on risk of coronary heart disease: the Adventist Health Study. Arch Intern Med 1992; 152:1416-24.

32. Greenland S, Morgenstern H. Ecological bias, confounding, and effect modification. Int J Epidemiol 1989; 18:269-74.
33. Benn MI. Wine and coronary heart disease (letter). Lancet 1992; 340:313.

34. Parra HJ, Arveiler D, Evans AE, Cambou J-P, Amouyel $P$, Bingham A, McMaster D, Schaffer $P$, Douste-Blazy $P$, Luc G, Richard JL, Ducimetiètr P, Fruchart JC, Cambien F. A case-control study of lipop-rotein particles in two populations at contrasting risk for coronary heart disease: the ECTIM Study. Arterioscler Thromb 1992; 12:701-7.

35. Ducimetière $P$, Richard JL, Cambien $F$, Rakotovao $R$, Claude JR. Coronary heart disease in middle-aged Frenchmen: comparisons between the Paris Prospective Study, Seven Countries Study, and Pooling Project. Lancet 1980; i: $1346-50$. 
